\title{
Front Matter: Volume 6967
}

, "Front Matter: Volume 6967," Proc. SPIE 6967, Automatic Target Recognition XVIII, 696701 (12 May 2008); doi: 10.1117/12.801999

SPIE Event: SPIE Defense and Security Symposium, 2008, Orlando, Florida, SPIE. United States 


\section{PROCEEDINGS OF SPIE}

\section{Automatic Target Recognition XVIII}

Firooz A. Sadjadi

Abhijit Mahalanobis

Editors

19-20 March 2008

Orlando, Florida, USA

Sponsored and Published by

SPIE

Volume 6967

Proceedings of SPIE, 0277-786X, v. 6967 
The papers included in this volume were part of the technical conference cited on the cover and title page. Papers were selected and subject to review by the editors and conference program committee. Some conference presentations may not be available for publication. The papers published in these proceedings reflect the work and thoughts of the authors and are published herein as submitted. The publisher is not responsible for the validity of the information or for any outcomes resulting from reliance thereon.

Please use the following format to cite material from this book:

Author(s), "Title of Paper," in Automatic Target Recognition XVIII, edited by Firooz A. Sadjadi, Abhijit Mahalanobis, Proceedings of SPIE Vol. 6967 (SPIE, Bellingham, WA, 2008) Article CID Number.

ISSN 0277-786X

ISBN 9780819471581

Published by

SPIE

P.O. Box 10, Bellingham, Washington 98227-0010 USA

Telephone +1 3606763290 (Pacific Time) · Fax +1 3606471445

SPIE.org

Copyright (C 2008, Society of Photo-Optical Instrumentation Engineers

Copying of material in this book for internal or personal use, or for the internal or personal use of specific clients, beyond the fair use provisions granted by the U.S. Copyright Law is authorized by SPIE subject to payment of copying fees. The Transactional Reporting Service base fee for this volume is $\$ 18.00$ per article (or portion thereof), which should be paid directly to the Copyright Clearance Center (CCC), 222 Rosewood Drive, Danvers, MA 01923. Payment may also be made electronically through CCC Online at copyright.com. Other copying for republication, resale, advertising or promotion, or any form of systematic or multiple reproduction of any material in this book is prohibited except with permission in writing from the publisher. The CCC fee code is $0277-786 \mathrm{X} / 08 / \$ 18.00$.

Printed in the United States of America.

Publication of record for individual papers is online in the SPIE Digital Library.

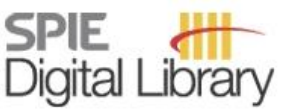

SPIEDigitallibrary.org

Paper Numbering: Proceedings of SPIE follow an e-First publication model, with papers published first online and then in print and on CD-ROM. Papers are published as they are submitted and meet publication criteria. A unique, consistent, permanent citation identifier (CID) number is assigned to each article at the time of the first publication. Utilization of CIDs allows articles to be fully citable as soon they are published online, and connects the same identifier to all online, print, and electronic versions of the publication. SPIE uses a six-digit CID article numbering system in which:

- The first four digits correspond to the SPIE volume number.

- The last two digits indicate publication order within the volume using a Base 36 numbering system employing both numerals and letters. These two-number sets start with 00, 01, 02, 03, 04, 05, $06,07,08,09,0 A, 0 B \ldots 0 Z$, followed by $10-12,20-2 Z$, etc.

The CID number appears on each page of the manuscript. The complete citation is used on the first page, and an abbreviated version on subsequent pages. Numbers in the index correspond to the last two digits of the six-digit CID number. 


\section{Contents}

vii Conference Committee

\section{SESSION 1 PERFORMANCE EVALUATION METHODS IN ATR I}

696702 The life and death of ATR/sensor fusion and the hope for resurrection (Invited Paper) [6967-01]

S. K. Rogers, Air Force Research Lab. (USA) and Qualia, LLC (USA); C. Sadowski, ACC/A8SI

(USA); K. W. Bauer, M. E. Oxley, Air Force Institute of Technology (USA); M. Kabrisky,

A. Rogers, Qualia, LLC (USA); S. D. Mott, Air Force Research Lab. (USA)

696704 Advancement in ATD performance prediction [6967-03]

R. Eaton, M. Snorrason, Charles River Analytics, Inc. (USA); J. Irvine, Science Applications International Corp. (USA); S. Vanstone, U.S. Army Aviation and Missile Research,

Development and Engineering Ctr. (USA)

696705 Clutter performance and confuser rejection on infrared data using distortion-invariant filters for ATR [6967-04]

R. Patnaik, D. Casasent, Carnegie Mellon Univ. (USA)

\section{SESSION 2 PERFORMANCE EVALUATION METHODS IN ATR II}

696706 Dynamic range compression deconvolution for enhancement of automatic target recognition system performance [6967-05]

B. Haji-saeed, Solid State Scientific Corp. (USA); J. Khoury, Air Force Research Lab. (USA);

W. D. Goodhue, Univ. of Massachusetts, Lowell (USA); C. L. Woods, Air Force Research Lab.

(USA); J. Kierstead, Solid State Scientific Corp. (USA)

696707 ROBIN: a platform for evaluating automatic target recognition algorithms: I. Overview of the project and presentation of the SAGEM DS competition [6967-06]

D. Duclos, J. Lonnoy, Q. Guillerm, SAGEM DS (France); F. Jurie, INRIA (France); S. Herbin,

ONERA (France); E. D'Angelo, DGA/DET/ASC/EORD (France)

696708 ROBIN: a platform for evaluating automatic target recognition algorithms: II. Protocols used for evaluating algorithms and results obtained on the SAGEM DS database [6967-07] D. Duclos, J. Lonnoy, Q. Guillerm, SAGEM DS (France); F. Jurie, INRIA (France); S. Herbin, ONERA (France); E. D'Angelo, DGA/DET/ASC/EORD (France)

\section{SESSION 3 HYPER-AND MULTISPECTRAL METHODS IN ATR}

6967 OA Rapid high-performance hyperspectral anomaly detection via global support vector data description (Invited Paper) [6967-09]

R. Meth, SET Corp. (USA); A. Banerjee, P. Burlina, Johns Hopkins Univ. (USA); T. Strat, SET Corp. (USA) 
6967 OB Deterministic hyperspectral target detection using the DWT and spectral fringe-adjusted joint transform correlation [6967-10]

W. A. Sakla, Texas A\&M Univ. (USA); A. A. Sakla, M. S. Alam, Univ. of South Alabama (USA)

6967 OC A variational method for target detection in hyperspectral images [6967-11]

A. Alarcón, V. Manian, Univ. of Puerto Rico at Mayagüez (Puerto Rico)

6967 OD Mine detection in multispectral imagery using PCA and matched filtering [6967-12]

M. M. Islam, M. S. Alam, Univ. of South Alabama (USA)

\section{SESSION 4 TARGET DETECTION AND CLASSIFICATION USING ACTIVE SENSORS I}

6967 OE New paradigms for active and passive 3D remote object sensing, visualization, and recognition (Keynote Paper) [6967-13]

P. F. McManamon, Air Force Research Lab. (USA); B. Javidi, Univ. of Connecticut (USA);

E. A. Watson, Air Force Research Lab. (USA); M. DaneshPanah, R. T. Schulein, Univ. of

Connecticut (USA)

6967 OF Target recognition using HRR profile-based incoherent SAR (InSAR) image formation [6967-14]

N. A. O'Donoughue, The MITRE Corp. (USA) and Carnegie Mellon Univ. (USA); W. S. Kuklinski,

C. Arabadjis, The MITRE Corp. (USA)

6967 OG Shape-based recognition of targets in synthetic aperture radar images using elliptical Fourier descriptors [6967-15]

L. P. Nicoli, G. C. Anagnostopoulos, Florida Institute of Technology (USA)

$6967 \mathrm{OH} \quad$ Analysis of spatially mismatched imagery for synthetic aperture radar ATR classification [6967-16]

C. T. Rupp, S. D. Halversen, L. J. Montagnino, C. L. Hebert, M. T. Young, M. L. Cassabaum, Raytheon Missile Systems (USA); N. KU, Raytheon Space and Airborne Systems (USA)

\section{SESSION 5 TARGET DETECTION AND CLASSIFICATION USING ACTIVE SENSORS II}

6967 Ol Dimensionality reduction and information-theoretic divergence between sets of LADAR images [6967-17]

D. M. Gray, Univ. of Florida (USA) and Air Force Research Lab. (USA); J. C. Príncipe, Univ. of Florida (USA)

6967 OK Particle swarm optimization for radar target recognition and modeling [6967-19]

I. Jouny, Lafayette College (USA)

$6967 \mathrm{OL}$ Utilization of volume correlation filters for underwater mine identification in LIDAR imagery [6967-20]

B. Walls, Areté Associates (USA) 
$6967 \mathrm{ON}$ Using radial basis functions to set thresholds for segmentation of signal from background on matched filter correlation surfaces [6967-22]

R. Edmondson, M. Rodgers, Polaris Sensor Technologies, Inc. (USA)

$696700 \quad$ Multi-frame adaptive object recognition [6967-23]

A. Mahalanobis, Lockheed Martin Missiles and Fire Control (USA)

6967 OP A performance comparison of the transform domain Rayleigh quotient quadratic correlation filter (TDRQQCF) approach to the regularized RQQCF [6967-24]

P. Ragothaman, Univ. of Central Florida (USA); A. Mahalanobis, R. Muise, Lockheed Martin Missiles and Fire Control (USA); W. B. Mikhael, Univ. of Central Florida (USA)

\section{SESSION 7 ADVANCED METHODS IN ATR I}

$69670 Q \quad$ Mixed state models for automatic target recognition and behavior analysis in video sequences (Invited Paper) [6967-25]

R. Chellappa, A. C. Sankaranarayanan, A. Veeraraghavan, Univ. of Maryland, College Park (USA)

6967 OR Tactical imagery and geospatial data support options for automatic target acquisition [6967-26]

N. K. Broderick, M. Podlesak, Defence Science \& Technology Organisation (Australia); P. Dare, Spatial Scientific Technologies Pty. Ltd. (Australia); S. D. Jones, Royal Melbourne Institute of Technology (Australia)

6967 OS Bayesian multi-target tracking and sequential object recognition [6967-27] W. Armbruster, FGAN-FOM Research Institute for Optronics and Pattern Recognition (Germany)

6967 OT A fast 2D/3D algorithm for georegistration and targeting [6967-28]

S. A. Merritt, Naval Air Warfare Ctr. (USA)

\section{SESSION 8 ADVANCED METHODS IN ATR II}

6967 OV Automatic detection in a maritime environment: gradient filter versus intensity background estimation [6967-30]

T. Y. C. van Valkenburg-van Haarst, Royal Netherlands Navy (Netherlands) and Univ. of Amsterdam (Netherlands); F. Bolderheij, Royal Netherlands Navy (Netherlands);

F. C. A. Groen, Univ. of Amsterdam (Netherlands)

6967 OW Edge feature extraction for ATR using the Helmholtz principle and level set methods [6967-31]

A. Flenner, NAVAIR (USA)

6967 0X Automatic target recognition from surveillance images using phase mutual information [6967-32]

S. Elmes, X. Jia, M. R. Pickering, The Univ. of New South Wales, Australian Defence Force Academy (Australia) 
6967 OY Biological models for automatic target detection (Invited Paper) [6967-33]

B. Schachter, Northrop Grumman Corp. (USA)

\section{SESSION 10 ADVANCED METHODS IN ATR IV}

$69670 Z$ A semantic approach to the efficient integration of interactive and automatic target recognition systems for the analysis of complex infrastructure from aerial imagery [6967-34] A. Baver, E. Peinsipp-Byma, Fraunhofer Institute for Information and Data Processing (Germany)

696710 Using non-negative matrix factorization toward finding an informative basis in spin-image data [6967-35]

A. J. Patterson, N. N. Shah, D. E. Waagen, Raytheon Missile Systems (USA)

696711 Object tracking and classification in aerial videos [6967-36]

J. Xiao, H. Cheng, H. Feng, C. Yang, Sarnoff Corp. (USA)

696712 Automatic target detection using vector quantization error [6967-37]

B. D. Wemett, VirtualScopics, Inc. (USA)

\section{SESSION 11 ADVANCED METHODS IN ATR V}

696713 Target detection and tracking using FKT, DCCF, and PDCCF and comparing these methods (Invited Paper) [6967-38]

M. S. Alam, M. S. Aslan, Univ. of South Alabama (USA)

696715 Multi-source feature extraction and target recognition in wireless sensor networks based on adaptive distributed wavelet compression algorithms [6967-40]

W. S. Hortos, Associates in Communications Engineering Research and Technology (USA)

696716 HRR signature classification using a hybrid composite classification system [6967-41] M. A. Turnbaugh, K. W. Bauer, Jr., Air Force Institute of Technology (USA)

\section{SESSION 12 ADVANCED METHODS IN ATR VI}

696717 Small unmanned aerial vehicle (UAV) real-time intelligence, surveillance, and reconnaissance (ISR) using onboard pre-processing [6967-42]

R. C. Stevens, F. A. Sadjadi, J. R. Braegelmann, A. M. Cordes, R. L. Nelson, Lockheed Martin Maritime Systems and Sensors (USA)

696719 Assessment of model-based automatic target recognition on recorded and simulated infrared imagery [6967-43]

H. Seidel, C. Stahl, W. Ensinger, European Aeronautic Defence and Space Co. (Germany); F. Bjerkeli, P. Skaaren-Fystro, K. Rosseland, P. I. Jensen, Kongsberg Defence \& Aerospace AS (Norway)

Author Index 


\title{
Conference Committee
}

\author{
Symposium Chair
}

Larry B. Stotts, Defense Advanced Research Projects Agency (USA)

Symposium Cochair

Ray O. Johnson, Lockheed Martin Corporation (USA)

Program Track Chair

Ivan Kadar, Interlink Systems Sciences, Inc. (USA)

Conference Chairs

Firooz A. Sadjadi, Lockheed Martin Corporation (USA)

Abhijit Mahalanobis, Lockheed Martin Missiles and Fire Control (USA)

Program Committee

Mohammad S. Alam, University of South Alabama (USA)

Farid Amoozegar, Jet Propulsion Laboratory (USA)

Mahmood R. Azimi-Sadjadi, Colorado State University (USA)

David P. Casasent, Carnegie Mellon University (USA)

Leon Cohen, Hunter College/CUNY (USA)

Belur V. Dasarathy, Consultant (USA)

Frederick D. Garber, Wright State University (USA)

Guillermo C. Gaunaurd, Army Research Laboratory (USA)

Izidor Gertner, City College/CUNY (USA)

Patti S. Gillespie, Army Research Laboratory (USA)

Riad I. Hammoud, Delphi Corporation (USA)

Bahram Javidi, University of Connecticut (USA)

Ismail I. Jouny, Lafayette College (USA)

Behrooz Kamgar-Parsi, Naval Research Laboratory (USA)

Timothy J. Klausutis, Air Force Research Laboratory (USA)

Wolfgang Kober, Data Fusion Corporation (USA)

Aaron D. Lanterman, Georgia Institute of Technology (USA)

Randolph L. Moses, The Ohio State University (USA)

Robert R. Muise, Lockheed Martin Missiles and Fire Control (USA)

Nasser M. Nasrabadi, Army Research Laboratory (USA)

Leslie M. Novak, BAE Systems Advanced Information Technologies (USA)

Joseph A. O'Sullivan, Washington University in St. Louis (USA)

Mubarak Shah, University of Central Florida (USA) 
S. Richard F. Sims, U.S. Army Aviation and Missile Research, Development and Engineering Center (USA)

Alan J. Van Nevel, Naval Air Warfare Center (USA)

Bradley C. Wallet, Automated Decisions LLC (USA)

Edmund G. Zelnio, Air Force Research Laboratory (USA)

\section{Session Chairs}

1 Performance Evaluation Methods in ATR I

Scott A. Merritt, Naval Air Warfare Center (USA)

2 Performance Evaluation Methods in ATR II

Scott A. Merritt, Naval Air Warfare Center (USA)

3 Hyper- and Multispectral Methods in ATR

Patti S. Gillespie, Army Research Laboratory (USA)

4 Target Detection and Classification using Active Sensors I

Arjuna Flenner, NAVAIR (USA)

5 Target Detection and Classification using Active Sensors II

Abhijit Mahalanobis, Lockheed Martin Missiles and Fire Control (USA)

6 Correlation-based Methods in ATR

Abhijit Mahalanobis, Lockheed Martin Missiles and Fire Control (USA)

$7 \quad$ Advanced Methods in ATR I

James C. Savage, Air Force Research Laboratory (USA)

8 Advanced Methods in ATR II

James C. Savage, Air Force Research Laboratory (USA)

9 Advanced Methods in ATR III

Robert R. Muise, Lockheed Martin Missiles and Fire Control (USA)

10 Advanced Methods in ATR IV

Robert R. Muise, Lockheed Martin Missiles and Fire Control (USA)

11 Advanced Methods in ATR V

Izidor Gertner, City College/CUNY (USA) 